\title{
A Comparative Study on the in vitro Antioxidant and Antimicrobial Potentials of Three Endemic Ononis L. Species from Turkey
}

\author{
Türkiye'den Üç Endemik Ononis L. Türünün in vitro Antioksidan ve \\ Antimikrobiyal Potansiyelleri Üzerine Karşılaştırmalı Bir Çalışma
}

\author{
(D) Ayşe BALDEMIR ${ }^{1 *}$, (D) Ayşegül KÖROĞLU², (D) Nurten ALTANLAR², (D) Maksut COŞKUN² \\ 'Erciyes University, Faculty of Pharmacy, Department of Pharmaceutical Botany, Kayseri, Turkey \\ ${ }^{2}$ Ankara University, Faculty of Pharmacy, Department of Pharmaceutical Botany, Ankara, Turkey \\ ${ }^{3}$ Ankara University, Faculty of Pharmacy, Department of Pharmaceutical Microbiology, Ankara, Turkey
}

\begin{abstract}
Objectives: In this study, the antioxidant capacity, antimicrobial activity and phenolic contents of aerial parts and roots extracts of three endemic Ononis L. (Leguminosae) species (O. sessilifolia Bornm., O. basiadnata Hub. \& Mor., O. macrosperma Hub. \& Mor.) were investigated for the first time. Materials and Methods: The phenolic contents of the extracts [water and ethanol (EtOH)] and fractions [dichloromethane, EtOAc and $n$-butanol] were determined using Folin-Ciocalteu's phenol reagent. Also, their antioxidant capacities were studied using qualitative DPPH (1,1-diphenyl-2picrylhdrazyl radical) and TBA assays. The antimicrobial activity of these extracts and fractions compared with standard antibiotics were studied using disc diffusion assays against various Gram-positive and Gram-negative bacteria and fungi.

Results: The total phenolic contents of the water extracts were found to range between $14.78-80.33 \mathrm{mg} / \mathrm{g}$, and the EtOH extracts ranged from 67.19 $145.33 \mathrm{mg} / \mathrm{g}$. EtOAc fractions of the three species were rich in terms of total phenolic contents when compared with other extracts (242.56-620.89 $\mathrm{mg} / \mathrm{g}$ ). The most significant results in the TBA assays were obtained in $\mathrm{EtOH}$ extracts of 0 . macrosperma $\left(\mathrm{IC}_{50}=0.13 \pm 0.17 \mu \mathrm{g} / \mathrm{mL}\right), 0$. sessilifolia $\left(\mathrm{IC}_{50}=1.41 \pm 0.58 \mu \mathrm{g} / \mathrm{mL}\right)$ and $\operatorname{root}\left(\mathrm{IC}_{50}=1.96 \pm 0.39 \mu \mathrm{g} / \mathrm{mL}\right)$.

Conclusion: EtOAc fractions rich in phenolic content were also found to be the most effective in antioxidant activity assays. Although all water extracts had no antimicrobial activity, EtOH extracts and $n$-butanol fractions showed generally moderate activity against bacteria. Some EtOAc fractions except for $O$. sessilifolia showed less activity against Escherichia coli, Staphylococcus aureus, MRSA and Candida albicans.
\end{abstract}

Key words: Ononis sessilifolia, Ononis basiadnata, Ononis macrosperma, antioxidant capacity, antimicrobial activity, endemic

öz

Amaç: Bu çalışmada üç endemik Ononis L. (Leguminosae) türünün (O. sessilifolia Bornm., O. basiadnata Hub. \& Mor., O. macrosperma Hub. \& Mor.) antimikrobiyal aktivite, antioksidan kapasite ve fenolik içerikleri ilk kez araştırılmıştır.

Gereç ve Yöntemler: Ekstrelerin [su ve etanol (EtOH)] ve fraksiyonların [diklorometan, etil astetat (EtOAc) ve $n$-butanol] fenolik içerikleri FolinCiocalteu'nun fenol reaktifi kullanılarak belirlendi. Ayrıca, antioksidan kapasiteleri kalitatif DPPH· (1,1-diphenyl-2-picrylhdrazyl radical) ve TBA deneyleri ile çalışıldı. Ekstre ve fraksiyonların antimikrobiyal aktivitesi disk difüzyon tekniği kullanılarak standart antibiyotiklere kıyaslanarak çeşitli Gram-pozitif, Gram-negatif ve mantara karşı çalışıldı.

Bulgular: Su ekstrelerinin toplam fenol içerikleri 14.78-80.33 mg/g aralığında değişirken, EtOH ekstreleri 67.19-145.33 mg/g aralığında bulunmuştur. Üç türün EtOAc fraksiyonları, diğer ekstrelerle $(242.56-620.89 \mathrm{mg} / \mathrm{g})$ karşılaştırıldığında toplam fenol içeriği bakımından zengindir. TBA metodundaki en önemli sonuçlar, O. macrosperma herba $\left(\mathrm{IC}_{50}=0.13 \pm 0.17 \mu \mathrm{g} / \mathrm{mL}\right)$, O. sessilifolia herba $\left(\mathrm{IC}_{50}=1.41 \pm 0.58 \mu \mathrm{g} / \mathrm{mL}\right)$ ve $\mathrm{kök}\left(\mathrm{IC} \mathrm{C}_{50}=1.96 \pm 0,39 \mu \mathrm{g} / \mathrm{mL}\right) \mathrm{EtOH}$ ekstraktlarında elde edildi.

Sonuç: Fenolik içerik bakımından zengin olan elilasetat fraksiyonları, antioksidan aktivite deneylerinde de en yüksek etkili olarak tespit edilmiştir. Su ekstrelerinin antimikrobiyal aktivitesi olmamasına rağmen, türlerin EtOH ekstreleri ve $n$-butanol fraksiyonları, bakterilere karşı genellikle orta düzeyde etkinlik gösterdi. O. sessilifolia dışında bazı EtOAc fraksiyonları, Escherichia coli, Staphylococcus aureus, MRSA ve Candida albicans'a karşı daha az aktivite gösterdi.

Anahtar kelimeler: Ononis sessilifolia, Ononis basiadnata, Ononis macrosperma, antioksidan kapasite, antimikrobiyal aktivite, endemik

*Correspondence: E-mail: aysebaldemir@gmail.com, Phone: +90 5368350757 ORCID-ID: orcid.org/0000-0003-2473-4837

Received: 31.03 .2017 , Accepted: 22.06.2017

Turk J Pharm Sci, Published by Galenos Publishing House. 


\section{INTRODUCTION}

Antioxidants have been recognized as potential therapeutics for preventing different human diseases (e.g., cancer, aging, cardiovascular diseases, asthma, acute central nervous system injury, neurodegenerative disease, and malaria).,2 Medicinal plants and herbs have played an important role in the health care of ancient and modern cultures. They are promising as natural antioxidant sources. ${ }^{3,4}$ The number of studies on new natural antioxidants with plant origin is increasing. ${ }^{5}$ Ononis L. genus (Leguminosae) is represented by 18 species, 4 of which are endemic to Turkey. ${ }^{6}$ The Ononis species has various pharmacologic properties, such as antioxidant, aperient, diuretic, antimicrobial, analgesic, antiviral, cytotoxic, antiinflammatory and anti-diarrheal activities. In Turkish folk medicine, $O$. spinosa $L$. has been used for the urinary tract, kidney stones, inflammatory diseases, wounds healing, and skin disorders. ${ }^{1,-9}$ Süntar et al..$^{10}$ reported that water and ethanolic extracts of the herb 0 . macrosperma demonstrated the highest activity in both wound models and anti-inflammatory activity. In previous studies, some Ononis species were found to contain different component groups such as isoflavone, triterpene, sterol, pterocarpane, and resorcinol derivatives, flavonoids, isocoumarins, and hydroxycinnamic acids. ${ }^{111-13} \mathrm{~A}$ DPPH (1,1-diphenyl-2-picrylhdrazyl radical) radical is a stable radical with maximum absorbance at $517 \mathrm{~nm}$, and when reduced to hydrazine derivatives by electron and hydrogen atom transfer from substances with antioxidant properties, its absorbance is decreased..$^{14}$ Lipid peroxidation is a chain reaction that causes the deterioration of biologic systems, and is the accumulative effect of reactive oxygen species. Reactive free radicals start the reaction by the deletion of allylic hydrogen atoms from the methylene group of unsaturated fatty acids. ${ }^{15}$ Thiobarbituric acid (TBA) and DPPH methods have been used to evaluate the antioxidant capacities of the plant extracts/ component. ${ }^{16}$ Medicinal plants represent potential sources of natural antioxidant and antimicrobial agents for food and medicinal purposes. The purpose of this investigation was to study antioxidant activities using TBA and DPPH [thin layer chromatography (TLC) screening], determine phenolic contents using spectrophotometry, and the antimicrobial activity with disc diffusion assays of herb and root extracts of three Ononis species. This is the first study on the antioxidant capacity and antimicrobial activities of the three Ononis species.

\section{MATERIALS AND METHODS}

\section{Plant materials}

Ononis species were gathered from different provinces of Turkey in their natural habitats. Voucher specimens were stored in the Herbarium of the Faculty of Pharmacy at the University of Ankara, Turkey (AEF). O. sessilifolia was collected from the Çamardı county of Niğde in June 2007 (AEF 23979); 0. basiadnata was collected from the Gülnar county of İçel in June 2007 (AEF 23968); and O. macrosperma was collected from the Elmalı county of Antalya in May 2008 (AEF 24698).

\section{Extraction of plants}

The herb and root of the 0 . basiadnata and 0 . sessilifolia and the herb of 0 . macrosperma were powdered and then $50 \mathrm{~g}$ of the herbs and roots were macerated separately with 500 $\mathrm{mL}$ of water for $5 \mathrm{~h}$ at $60^{\circ} \mathrm{C}$. Afterwards, the water extracts were filtered, frozen, and lyophilized. One hundred grams of plant material was macerated with ethanol ( $\mathrm{EtOH})$ for $5 \mathrm{~h}$ at $50^{\circ} \mathrm{C}$. The extracts were then filtered and evaporated until dry. Ethanolic extracts were dispersed in methanol: water (1:9), partitioned with dichloromethane (DCM), ethyl acetate (EtOAc) and $n$-butanol (BuOH). Afterward, the fractions were evaporated until dry.

\section{Determination of total phenolic content}

The total phenolic contents of extracts were evaluated using the Folin-Ciocalteu assay as gallic acid equivalents (GAE). ${ }^{17}$

\section{Antioxidant capacities of extracts}

DPPH test

The antioxidant capacity of extracts $(\mathrm{EtOH}$ and water extracts; $\mathrm{DCM}, \mathrm{EtOAc}$ and $\mathrm{BuOH}$ fractions) were evaluated with rapid TLC screening. ${ }^{18}$

\section{TBA test (measurement of malondialdehyde value)}

The amount of malondialdehyde formed in the reaction mixture was determined using the TBA reagent spectrophotometrically. ${ }^{18}$

\section{Antimicrobial activity}

\section{Test microorganisms}

The test microorganisms used in the experiment were Gram-positive bacteria (Staphylococcus aureus ATCC 25923, Staphylococcus aureus (MRSA) (clinical isolate), Bacillus subtilis ATCC 25923); Gram-negative bacteria (Escherichia coli ATCC 25922) and fungus: (Candida albicans ATCC 10231).

Ampicillin sulbactam $(20 \mu \mathrm{g})$, ciprofloxacin $(5 \mu \mathrm{g})$, fluconazole $(25 \mu \mathrm{g})$ and cefotaxime $(30 \mu \mathrm{g})$ were used as control drugs. ATCC strains were obtained from the culture collection of the Refik Saydam Health Institution of Health Ministry, Ankara.

\section{Media}

Mueller-Hinton agar (Difco, Detroit, MI, USA) was used for bacteria, and MHA supplemented with $2 \%$ glucose and $0.5 \mu \mathrm{g} /$ $\mathrm{mL}$ methylene blue was used for $C$. albicans.

\section{Disc diffusion assay}

Antimicrobial activities of the extracts and fractions were evaluated by using the disc diffusion technique. 19,20

\section{RESULTS}

Phenolic compounds are known as a main class of active compounds determined by Folin-Ciocalteu assay. The highest total phenolic contents of all extracts and fractions of the three species were determined in the EtOAc fractions. The results of total phenolic contents of extracts and fractions are shown in Table 1.

When all DCM fractions and EtOAc fractions, excluding 0 . basiadnata root, were compared using propyl gallate, they were 
Table 1. Total phenolic contents of the extracts and fractions of Ononis species

\begin{tabular}{lllllc}
\multirow{2}{*}{ Species } & \multicolumn{2}{l}{ Total phenolic contents $\left(\mathrm{mg}_{\text {gallic acid }} / \mathrm{g}_{\text {extr }}\right) \pm \mathrm{SD}$} & & \\
\cline { 2 - 7 } & Water extracts & EtOH extracts & DCM fraction & EtOAc fraction & BuOH fraction \\
\hline O. sessilifolia herb $(\mathrm{OSH})$ & $37.19 \pm 1.58$ & $132.01 \pm 4.16$ & $208.11 \pm 3.93$ & $413.67 \pm 5.50$ & $124.77 \pm 0.79$ \\
\hline O. sessilifolia root $(\mathrm{OSR})$ & $14.78 \pm 0.79$ & $145.33 \pm 1.57$ & $221.44 \pm 2.36$ & $327.08 \pm 0.79$ & $131.44 \pm 2.36$ \\
\hline O. basiadnata herb (OBH) & $80.33 \pm 0.79$ & $111.44 \pm 0.79$ & $105.33 \pm 4.16$ & $620.89 \pm 12.57$ & $89.77 \pm 4.71$ \\
\hline O. basiadnata root (OBR) & $20.15 \pm 0.64$ & $91.17 \pm 5.55$ & $119.22 \pm 2.36$ & $242.56 \pm 4.84$ & $88.11 \pm 0.79$ \\
\hline O. macrosperma herb (OMH) & $46.17 \pm 3.78$ & $67.19 \pm 0.64$ & $63.67 \pm 4.21$ & $467.03 \pm 3.93$ & $156.44 \pm 4.71$ \\
\hline
\end{tabular}

*SD: Standard deviation, EtOH: Ethanol, DCM: Dichloromethane, EtOAc: Ethyl acetate, BuOH: n-butanol

Table 2. Antioxidant capacities of extracts and fractions of Ononis species in TBA test

\begin{tabular}{|c|c|c|c|c|c|}
\hline \multirow{2}{*}{ Species } & \multicolumn{5}{|c|}{$\mathrm{IC}_{50}$ value $(\mu \mathrm{g} / \mathrm{mL}) \pm \mathrm{SD}^{*}$} \\
\hline & Water ext. & EtOH ext. & DCM frac. & EtOAc frac. & BuOH frac. \\
\hline $\mathrm{OSH}$ & $\mathrm{NE}^{*}$ & $1.41 \pm 0.58$ & $14.38 \pm 1.32$ & $51.18 \pm 3.31$ & $\mathrm{NE}$ \\
\hline OSR & $>1000 \pm 8.55$ & $1.96 \pm 0.39$ & $26.03 \pm 0.24$ & $146.35 \pm 2.73$ & $\mathrm{NE}$ \\
\hline $\mathrm{OBH}$ & $>1000 \pm 3.11$ & $24.19 \pm 2.21$ & $49.73 \pm 1.41$ & $532.01 \pm 5.58$ & $\mathrm{NE}$ \\
\hline OBR & $>1000 \pm 7.99$ & $15.57 \pm 0.95$ & $26.06 \pm 1.19$ & $3.10 \pm 1.14$ & $138.93 \pm 2.26$ \\
\hline $\mathrm{OMH}$ & $\mathrm{NE}$ & $0.13 \pm 0.17$ & $>1000 \pm 2.85$ & $61.56 \pm 3.61$ & $570.41 \pm 7.14$ \\
\hline
\end{tabular}

Propyl gallate $\quad 3.72 \pm 1.6$

*Non-effective; SD: Standard deviation, OSH: 0 . sessilifolia herb, OSR: 0 . sessilifolia root, OBH: 0 . basiadnata herb, OBR: 0 . basiadnata root, OMH: 0 . macrosperma herb, EtOH: Ethanol, DCM: Dichloromethane, EtOAc: Ethyl acetate, BuOH: n-butanol

Table 3. Results of the antimicrobial activity of $O$. sessilifolia herb (OSH) and root (OSR) extracts (inhibition zones in mm)

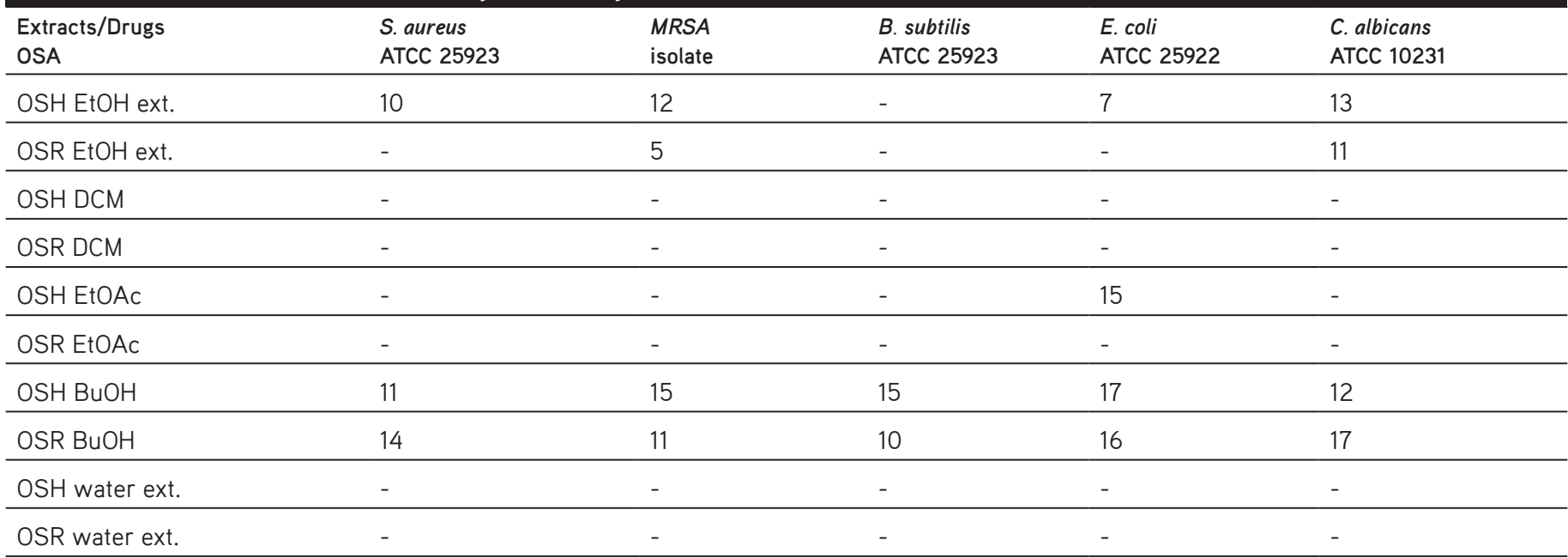

OSH: O. sessilifolia herb, OSR: O. sessilifolia root, EtOH: Ethanol, DCM: Dichloromethane, EtOAc: Ethyl acetate, BuOH: $n$-butanol

shown to have a high radical scavenging effect with qualitative DPPH. Yellow zones on a purple ground were marked for the DCM and EtOAc fractions of all species. In DPPH test, EtOH extracts were generally active from the water extract, especially the root and herb extracts of $O$. sessilifolia (Figure 1).

The most significant results in the TBA method were obtained in $\mathrm{EtOH}$ extracts of $O$. macrosperma herb $(\mathrm{OMH})\left(\mathrm{IC}_{50}=0.13 \pm 0.17\right.$ $\mu \mathrm{g} / \mathrm{mL})$, O. sessilifolia herb $\left(\mathrm{IC}_{50}=1.41 \pm 0.58 \mu \mathrm{g} / \mathrm{mL}\right)$ and root

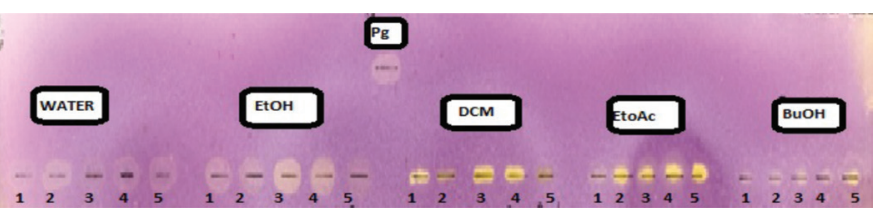

Figure 1. Antioxidant capacity by qualitative DPPH test on TLC of Ononis species 1: 0 . basiadnata root extract, 2: 0 . basiadnata herb extract, 3. 0 . sessilifolia root extract, 4: 0 . sessilifolia herb extract, 5: O. macrosperma herb extract, Pg: Propyl gallate 
$\left(\mathrm{IC}_{50}=1.96 \pm 0.39 \mu \mathrm{g} / \mathrm{mL}\right.$ ) (Table 2). A survey of the published literature shows that the antioxidant activity of $O$. sessilifolia, $O$. basiadnata and $O$. macrosperma has not been subjected to research so far.

In our antimicrobial activity studies, the extracts and fractions of three endemic Ononis species were examined against various bacteria and fungi. First, EtOH extracts were prepared, and then extracted with $\mathrm{DCM}, \mathrm{EtOAc}$ and $\mathrm{BuOH}$. The antimicrobial activity of the water extract was also examined. Water extracts of herb and root parts had no antimicrobial activity against Gram (-), Gram (+) bacteria and yeast. All of the $\mathrm{BuOH}$ extracts showed moderate activity compared with the standards. Some EtOAc fractions also demonstrated less activity against $E$. coli, S. aureus, MRSA and C. albicans. Apart from $\mathrm{OMH}$, other DCM extracts showed no activity against Gram (+), Gram (-) bacteria and fungi. All EtOH extracts showed less activity against some bacteria. In addition to this, they showed moderate activity against $C$. albicans according to fluconazole (Table $3,4,5,6$ ).

\section{DISCUSSION}

In the literature, there are some studies on the antioxidant activities and phenolic contents of other Ononis species. Leaf methanolic extract of $O$. natrix has significant total phenolic content (51 mg GAE/g DW) and flavonoid content (14.76 CE/g DW). ${ }^{21}$ The antioxidant activity and total phenolic contents of 0 . natrix used in folk medicine in Jordanian were identified as follows: according to antioxidant capacity results, the aqueous extract has $82.0 \pm 1.5 \mu \mathrm{mol} \mathrm{TE} / \mathrm{g}$, methanolic extract has $76.7 \pm 2.0$ $\mu \mathrm{mol}$ TE/g dry weight; in total phenolic content, the aqueous extract has $16.9 \pm 0.4 \mathrm{mg} \mathrm{GAE} / \mathrm{g}$, methanolic extract has $21.1 \pm 0.7$ mg GAE/g dry weight. ${ }^{9}$ In another study, 0 . spinosa root infusion was evaluated in both DPPH inhibition (20.5 $\pm 0.8 \%$ ) and total phenolic content $3.09 \pm 0.01 \mathrm{mg} \mathrm{GAE} / \mathrm{g}$ extract. ${ }^{22}$ Although the ethanolic extract of $O$. spinosa indicated concentrationdependent superoxide anion radical scavenging capacity $\left(\mathrm{IC}_{50}=1.35 \mathrm{mg} / \mathrm{mL}\right)$, the extract showed no concentrationdependent inhibitory effect on lipid peroxidation. ${ }^{23}$ Unlike the present study, in our lipid peroxidation experiment, significant results were obtained (Table 2 ).

Table 4. Results of the antimicrobial activity of 0 . basiadnata herb (OBH) and root (OBR) extracts (inhibition zones in mm)

\begin{tabular}{|c|c|c|c|c|c|}
\hline $\begin{array}{l}\text { Extracts/Drugs } \\
\text { OBA }\end{array}$ & $\begin{array}{l}\text { S. aureus } \\
\text { ATCC } 25923\end{array}$ & $\begin{array}{l}\text { MRSA } \\
\text { isolate }\end{array}$ & $\begin{array}{l}\text { B. subtilis } \\
\text { ATCC } 25923\end{array}$ & $\begin{array}{l}\text { E. coli } \\
\text { ATCC } 25922\end{array}$ & $\begin{array}{l}\text { C. albicans } \\
\text { ATCC } 10231\end{array}$ \\
\hline $\mathrm{OBH}$ EtOH ext. & 11 & - & 12 & 10 & 11 \\
\hline $\mathrm{OBH}$ DCM & - & - & - & - & - \\
\hline $\mathrm{OBH}$ EtOAc & 10 & 11 & - & - & 7 \\
\hline OBR EtOAc & - & - & - & 14 & - \\
\hline $\mathrm{OBH} \mathrm{BuOH}$ & 12 & 12 & 14 & 14 & - \\
\hline OBR BuOH & 11 & 14 & 17 & 17 & 14 \\
\hline
\end{tabular}

OSR: O. sessilifolia root, OBH: O. basiadnata herb, OBR: O. basiadnata root, OMH: O. macrosperma herb, EtOH: Ethanol, DCM: Dichloromethane, EtOAc: Ethyl acetate, BuOH: $n$-butanol

Table 5. Results of the antimicrobial activity of 0 . macrosperma herb $(\mathrm{OMH})$ extracts (inhibition zones in $\mathrm{mm}$ )

\begin{tabular}{llllll}
$\begin{array}{l}\text { Extracts/ } \\
\text { Drugs }\end{array}$ & $\begin{array}{l}\text { S. aureus } \\
\text { ATCC }\end{array}$ & $\begin{array}{l}\text { MRSA } \\
\text { Isolate }\end{array}$ & $\begin{array}{l}\text { B. subtilis } \\
\text { ATCC } \\
25923\end{array}$ & $\begin{array}{l}\text { E. coli } \\
\text { ATCC } \\
25922\end{array}$ & $\begin{array}{l}\text { C. albicans } \\
\text { ATCC } \\
10231\end{array}$ \\
\hline EtOH ext. & 10 & 9 & - & - & 16 \\
\hline DCM frac. & 12 & - & - & 7 & - \\
\hline EtOAc fract. & - & 10 & - & - & - \\
\hline BuOH frac. & 12 & 15 & - & 16 & 13 \\
\hline Water ext. & - & - & - & - & - \\
\hline
\end{tabular}

$\mathrm{OMH}$ : O. macrosperma herb, EtOH: Ethanol, DCM: Dichloromethane, EtOAc: Ethyl acetate, $\mathrm{BuOH}: n$-butanol

\begin{tabular}{|c|c|c|c|c|c|}
\hline $\begin{array}{l}\text { Reference } \\
\text { Substances }\end{array}$ & $\begin{array}{l}\text { S. aureus } \\
\text { ATCC } \\
25923\end{array}$ & $\begin{array}{l}\text { MRSA } \\
\text { isolate }\end{array}$ & $\begin{array}{l}\text { B. subtilis } \\
\text { ATCC } \\
25923\end{array}$ & $\begin{array}{l}\text { E. coli } \\
\text { ATCC } \\
25922 \\
\end{array}$ & $\begin{array}{l}\text { C. albicans } \\
\text { ATCC } 10231\end{array}$ \\
\hline $\begin{array}{l}\text { Ampicillin } \\
\text { sulbactam }\end{array}$ & 30 & - & 21 & - & - \\
\hline Ciprofloxacin & - & 27 & - & - & - \\
\hline Fluconazole & - & - & - & - & 32 \\
\hline Cefotaxime & - & - & - & 25 & - \\
\hline
\end{tabular}


The present study shows that the three Ononis species contained phenolic compounds, which inhibit the oxidation of lipids by donating hydrogen atoms to scavenge free radicals. ${ }^{24}$ Phenolic compounds have been shown to be more effective antioxidants than vitamin $A$ and $C .{ }^{25}$ Our results showed that there seemed to be good compatibility between the phenolic content and antioxidant capacity of the extracts because the EtOAc fractions with a higher phenolic content showed higher DPPH radical scavenging capacity.

According to previous studies, the $\mathrm{BuOH}$ extracts of $O$. spinosa ( $4 \mathrm{mg} / \mathrm{disc}$ ) had moderate antifungal activity against Aspergillus flavus, Fusarium moniliforme and C. albicans in comparison with miconazole nitrate at $40 \mu \mathrm{g} /$ disc. Petroleum benzene, $\mathrm{EtOH}$, and water extracts showed high activity against Gram (+) and Gram (-) bacteria. ${ }^{26}$ In another study, EtOH extract of O. spinosa demonstrated significant activity against Gram-positive ( $E$. coli and $P$. aeruginosa), Gram-negative ( $S$. aureus) bacteria and fungi (C. albicans). ${ }^{27}$ In our study, similar results were obtained, $\mathrm{EtOH}$ extracts and $\mathrm{BuOH}$ fractions of all species showed generally high activity against Gram (+), Gram negative (-) bacteria and C. albicans.

\section{CONCLUSION}

Further studies are being conducted to determine the characterization and identification of active components responsible for the antioxidant and antimicrobial activities. Natural products are commonly a source for active compounds that have important potential for developing new therapeutic agents. Ononis species can be introduced as new plant source for antioxidant and antimicrobial agents.

Conflict of Interest: No conflict of interest was declared by the authors.

\section{REFERENCES}

1. Erdemgil FZ, Kurkçüoğlu M, Başer KHC. Composition of the Essential Oil of Ononis viscosa subsp. Breviflora. Chemisttry of Natural Compounds. 2002;38:565-567.

2. Xue Y, Zheng Y, An L, Dou Y, Liu Y. Density functional theory study of the structure-antioxidant activity of polyphenolic deoxybenzoins. Food Chem. 2014;151:198-206.

3. Erdemoğlu N, Turan NN, Çakici I, Sener B, Aydin A. Antioxidant activities of some Lamiacaeae plant extracts. Phytother Res. 2006;20:9-13.

4. Narayanaswamy N, Balakrishnan KP. Evaluation of some Medicinal Plants for their Antioxidant Properties. Intern J Pharm Tech Res. 2011;3:381-385.

5. Saeed N, Khan MR, Shabbir M. Antioxidant activity, total phenolic and total flavonoid contents of whole plant extracts Torilis leptophylla L. BMC Complement Altern Med. 2012;12:221.

6. Güner A. Türkiye Bitkileri Listesi (Damarlı Bitkiler), Nezahat Gökyiğit Botanik Bahçesi Yayınları; İstanbul; 2012.

7. Mükemre M, Behçet L, Çakılcıoğlu U. Ethnobotanical study on medicinal plants in villages of Çatak (Van-Turkey). J Ethnopharmacol. 2015;166:361374.
8. Bremner P, Rivera D, Calzado MA, Obon C, Inocencio C, Bechwith C, Fiebich BL, Munoz E, Heinrich M. Assessing Medicinal Plants from South-Eastern Spain for potential anti-inflammatory effects targeting nuclear factor- Kappa B and other pro-inflammatory mediators. J Ethnopharmacol. 2009;124:295-305.

9. Tawaha K, Alali FQ, Gharaibeh M, Mohammed M, El-Elimat T. Antioxidant activity and total phenolic content of selected Jordanian plant species. Food Chem. 2007;104:1372-1378.

10. Süntar I, Baldemir A, Coşkun M, Keleş H, Akkol EK. Wound Healing acceleration effect of endemic Ononis species growing in Turkey. $\mathrm{J}$ Ethnopharmacol. 2011;135:63-70.

11. Barrero AF, Cabrera E, Rodriguez I, Fernandez-Gallego EM. Resorcinol derivatives and other components from Ononis viscosa subsp. breviflora. Phytochem. 1993;36:189-194.

12. Barrero AF, Cabrera E, Rodriguez I, Planelles F. Alkylresorcinols and Isocoumarins from Ononis pubescens. Phytochem. 1994;35:493-498.

13. Abdel-Kadel MS. Phenolic Constituents of Ononis vaginalis Roots. Planta Med. 2001;67:388-390.

14. Hinneburg I, Dorman HJD, Hiltunen R. Antioxidant activities of extracts from selected culinary herbs and spices. Food Chem. 2006;97:122-129.

15. Badmus JA, Adedosu TO, Fatokı JO, Adegbite, VA, Adaramoye OA, Odunola OA. Lipid peroxidation inhibition and antiradical activities of some leaf fractions of Mangifera indica. Acta Pol Pharm. 2011;68:23-29.

16. Saha K, Lajis NH, Israf DA, Hamzah AS, Khozirah S, Khamis S, Syahida A. Evaluation of antioxidant and nitric oxide inhibitory activities of selected Malaysian medicinal plants. J Ethnopharmacol. 2004;92:263-267.

17. Singleton VL, Rossi JA. Colorimetry of total phenolics with phosphomolybdic-phosphotungstic acid reagents. Am J Enol Vitic. 1965;16:144-158.

18. Güvenç A, Houghton PJ, Duman H, Coşkun M, Şahin P. Antioxidant activity studies on selected Sideritis Species Native to Turkey. Pharm Bio. 2005;43:173-177.

19. Shadomy S, Pfalle MA. Laboratory studies with antifungal agents: susceptibility tests and quantition in body fluids. Manual of Clinical Microbiology, American Society for Microbiology, Washington DC; 1991.

20. Clinical Laboratory Standards Institute, Performance standards for antimicrobial susceptibility testing. Twenty-second informational supplement ed. CLSI document M100 S22. CLSI: Wayne PA; 2008.

21. Mhamdi B, Abbassi F, Abdelly C. Chemical composition, antioxidant and antimicrobial activities of the edible medicinal Ononis natrix growing wild in Tunusia. Nat Prod Res. 2014:29:1157-1160.

22. Deliorman Orhan D, Özçelik B, Hoşbaş S, Vural M. Assessment of antioxidant, antibacterial, antimycobacterial, and antifungal activities of some plants used as folk remedies in Turkey against dermatophytes and yeast-like fungi. Turk J Biol. 2012;36:672-686.

23. Coban T, Saltan Citoglu G, Sever B, Iscan M. Antioxidant activities of plants in traditional medicine in Turkey. Pharm Bio. 2003;41:608-613.

24. Zhang HY. Selection of theoretical parameter characterizing scavenging activity of antioxidant on free radicals. J Am Oil Chem Soc. 1998;75:1705-1709.

25. Celep E, Aydın A, Yesilada E. A comparative study on the in vitro antioxidant potentials of three edible fruits: cornelian cherry, Japanese persimmon and cherry laurel. Food Chem Toxicol. 2012;50:3329-3335.

26. Mahasneh AM, El-Oqlah AA. Antimicrobial Activity of Extracts of Herbal Plants used in the Traditional Medicine of Jordan. J Etnopharmacol. 1999;64:271-276.

27. Saltan Çitoglu G, Altanlar N. Antimicrobial activity of some plants used in folk medicine. J Fac Pharm Ankara. 2003;32:159-163. 